\title{
ULAMA PEREMPUAN DAN DEDIKASINYA DALAM PENDIDIKAN ISLAM (Telaah Pemikiran Rahmah El-Yunusiyah)
}

\author{
Rohmatun Lukluk Isnaini \\ (UIN Sunan Kalijaga Yogyakarta)
}

\begin{abstract}
Abstrak:
Istilah ulama biasanya identik dengan laki-laki, namun disini Rahmah ElYunusiyah bisa disebut dengan ulama karena banyak hal yang melekat pada dirinya bisa merepresentasikan sebagai seorang alim yang mempunyai kapasitas keilmuan yang mumpuni tentang agama, sikap progresifnya untuk memperjuangkan kaumnya hingga pengakuan dari masyarakat luas baik di Indonesia hingga dunia internasional terhadap kiprahnya dalam pembaharuan pendidikan bagi perempuan. Tulisan ini menelaah pemikiran Rahmah El-Yunusiyah tentang pendidikan perempuan dijamannya melalui penelusuran buku-buku teks sejarah dan berbagai literatur. Penulis berusaha menyajikan gambaran sejarah perjuangan pendidikan bagi perempuan yang telah dilakukan Rahmah El-Yunusiyah sebagai fakta sejarah tentang peran penting perempuan dalam bersosial masyarakat sehingga perlu untuk terus diperjuangkan hingga saat ini. Sebagaimana yang telah dilakukan Rahmah El-Yunusiyah sebagai pembaharu pendidikan bagi perempuan dengan mendirikan sekolah khusus perempuan dari jenjang sekolah dasar hingga perguruan tinggi. Kontribusinya dalam memperjuangkan pendidikan perempuan sangat besar, terlihat sekarang perempuan Indonesia telah dapat secara mudah untuk dapat mengakses pendidikan. Betapa perempuan sebagai tiang negara memiliki andil besar dalam menentukan masa depan bangsa.
\end{abstract}

Kata Kunci: Ulama, Pendidikan Perempuan, Rahmah El-Yunusiyah 


\begin{abstract}
:
The term of ulama is usually identical to men. However, Rahmah ElYunusiyah is also called as an ulama because of several factors attached to herself such as representation as an alim with religious knowledge capacity, progressive attitudes for her community development, and recognition of wider community both in Indonesia and in international regarding her work in woman education reform. This paper examines Rahmah El-Yunusiyah's consideration about female education in the past through historical texts and related literatures. The author attempt to present a historical overview of El-Yunusiyah's struggle for women's education as the historical facts about the important role of women in society. El-Yunusiyah was as a reformer of woman education who set up woman school of the primary level up to the university level. Her great contribution in education is now visible that Indonesian women have easy access to education. This effort shows that women as a pillar of the state has a big responsibility to determine the future of the nation.
\end{abstract}

\title{
Keywords: Ulama, Women's Education, Rahmah El-Yunusiyah
}

\section{A. Pendahuluan}

Menilik sejarah pendidikan Islam Nusantara jaman sebelum dan sesudah kemerdekaan Indonesia, peran perempuan hanya sebatas dirumah. Karena tidak semua perempuan berhak mendapatkan pendidikan. Paradigma masyarakat tentang perempuan hanyalah makhluk lemah yang tidak mempunyai kiprah luas dalam ranah publik di masyarakat lingkungannya. Dan masyarakat memandang perempuan hanyalah makhluk kelas dua yang tidak perlu bersekolah. Percuma bersekolah jika akhirnya hanya masuk ke dapur. Perempuan masa itu sangat pasif dan belum mampu memberikan kontribusi riil bagi kemajuan agama dan bangsanya.

Selain itu, kemungkinan yang melatar belakangi kesenjangan ini adalah masih kentalnya budaya dalam masyarakat yang beranggapan bahwa anak perempuan belum diinginkan berpendidikan tinggi, para orang tua sudah merasa cukup jika wanita telah mendapat pendidikan dasar, kemudian diberi ketrampilan rumah tangga agar siap menjadi ibu atau istri. Perempuan tidak dapat berkiprah dalam lingkungan sosial karena pergaulannya sangat dibatasi.

Berbeda halnya, ketika disepakati bahwa sarana utama bagi suatu proses pembentukan atau pengembangan potensi individu, fitrah, sumber daya insani atau apapun namanya adalah melalui pendidikan, maka hak untuk memperoleh layanan tersebut (pendidikan) tentu merupakan bagian paling mendasar bagi setiap individu siapa dan dimanapun ia berada. Berdasarkan hal itulah dapat 
dimengerti mengapa dalam bahasan Islam and Women's Education, Haiffa A. Jawad mengemukakan bahwa salah satu hak terpenting bagi kaum wanita di dalam Islam adalah hak untuk memperoleh pendidikan. ${ }^{1}$

Sebenarnya secara konseptual Islam tidak ada persoalan yang layak diperdebatkan tentang pentingnya arti pendidikan bagi kehidupan manusia baik itu bagi laki-laki maupun perempuan. Karena jelas disebutkan bahwa menuntut ilmu itu wajib bagi setiap muslim laki-laki dan perempuan. Pentingnya pendidikan bagi perempuan juga berkaitan erat dengan peran penting mereka dalam peningkatan kualitas generasi muda. Dalam hal ini diperlukan adanya peningkatan kesadaran pada seorang ibu terhadap tanggung jawab dan perannya sebagai pendidik pertama dan utama.

Merupakan suatu yang kodrati bahwa perempuan yang melahirkan anak, membesarkan generasi bangsa yang secara alamiah ia memiliki hubungan emosional yang paling dekat dengan anak. Sesuai dengan harkat, martabat dan kodratnya, kaum perempuan mempunyai peran yang sangat besar dan menentukan. Merekalah yang membentuk, menentukan, dan memberi warna kualitas generasi muda bangsa. Karena itu tidaklah berlebihan apabila dikatakan bahwa, berada ditangan perempuan kualitas generasi muda, penerus cita-cita perjuangan itu ditentukan. Sebuah pepatah Arab mengatakan: "Al-Mar'ah 'Imad alBilad. Idza shaluhat shaluha al-Bilad, wa idza fasadat fasada al-bilad" (perempuan adalah pilar negara, bila baik, maka negara akan menjadi baik, bila ia rusak, maka hancurlah negara). Secara literal, kata shaluha atau shalih berarti baik, sehat, patut, kukuh, bermanfaat, damai, sesuai dan sebagainya. ${ }^{2}$ Jadi, arti dari shaluha atau saleh tidak hanya diartikan sebatas aspek kebaikan moral individu atau personal tapi lebih dari kebaikan moral secara sosial yang meliputi kesehatan fisik dan mental, cerdas secara nalar pikiran sehingga mampu mengaktualisasikan diri dalam ranah publik segala ruang.

Semua yang harus diketahui oleh kaum perempuan itu tidak bisa terjadi secara serta-merta. Semuanya harus melalui pendidikan dan pengajaran, perempuan harus dituntut untuk terus belajar dan berupaya untuk memahami persoalan yang ada di sekitar mereka. Selama mereka masih berada dalam kebodohan, maka nasib kaum perempuan itu tidak akan berubah. Oleh karena itu Rahmah El-Yunusiyah berpendapat bahwa wanita itu harus mendapatkan akses pendidikan, sebagaimana kaum laki-laki mendapatkan kesempatan yang sama.

${ }^{1}$ Haiffa A. Jawad, The Rights of Women in Islam: An Authentic Approach (New York: St. Martin's Press, Inc., 1998), 16.

2 Ibn Manzur, Lisān al-'Arab II (1290), 516-517. Lihat juga Syauqi Dhaif, Almu’jam Alwasịt I (Kairo: Maktabah Shurouq ad-Dauliyyah, 2011), 520. 
Hak untuk mempunyai ilmu pengetahuan dan pendidikan antara perempuan dan laki-laki adalah sama. Karena pada dasarnya teks-teks Al-Qur'an juga telah banyak menjelaskan dan memberikan ruang terhadap hak-hak kemanusiaan perempuan berupa hak asasi pendidikan. Sesungguhnya keluhuran dan keunggulan manusia itu didasarkan atas kebaikan budinya. Dan begitulah ajaran Islam menaruh perhatian yang sangat besar terhadap umatnya yang menuntut ilmu dengan tidak membedakan apakah itu laki-laki atau perempuan.

Namun, jika melihat pada sistem pendidikan sebelumnya yang bercorak tradisional masih kurang memberikan akses bagi perempuan. Selain itu kurang penekanannya terhadap akses untuk masuk dunia kerja dan kesempatan lain. Dalam situasi masyarakat yang pada saat itu sedang berkembang inilah Rahmah El-Yunusiah tergugah hatinya untuk berkiprah. Ia menaruh perhatian khusus terhadap pendidikan kaum perempuan. Karena Ia menyadari bahwa pendidikan menjadi sarana utama bagi peningkatan posisi kaumnya.

Dan pada saat ini, bila melihat keadaan perempuan sekarang yang telah mendapatkan tempat berkiprah dalam ranah publik, lingkungan sosial dan memperoleh hak pendidikan tidak terlepas dari perjuangan ulama perempuan Islam nusantara, Syaikhah Rahmah El-Yunusiah. Karena dalam mempelajari sejarah pendidikan Islam nusantara khususnya pendidikan bagi perempuan tidak dapat terlepas dari pemikiran Rahmah El-Yunusiah. Sejarah banyak mencatat kiprahnya dalam memperjuangkan pendidikan perempuan Islam Indonesia. Semasa hidupnya (1900-1969 M) telah didedikasikan untuk pendidikan perempuan Indonesia.

Bermula dari keprihatinannya terhadap nasib perempuan dijamannya yang disebabkan adanya ketidaksetaraan kesempatan belajar antara laki-laki dan perempuan. Maka dari itu, perjuangannya untuk perempuan diwujudkannya dengan pendirian madrasah khusus perempuan yang dinamai Madrasah Diniyyah putri di tanah Minangkabau sebagai pembaharuan pendidikan Islam bagi perempuan. Dari tulisan ini diharapkan dapat memberikan penjelasan tentang sejarah pendidikan Islam nusantara khususnya pendidikan bagi perempuan melalui konsep pemikiran tokoh perempuan Rahmah El-Yunusiah pada masa sebelum dan sesudah kemerdekaan.

\section{B. Biografi Rahmah El-Yunusiah}

Nama Rahmah El-Yunusiah tidak tercatat sebagai salah satu nama pahlawan nasional. Namanya juga masih asing didengar dan belum banyak dikenal di dunia pendidikan. Tidak semasyhur nama besar pahlawan wanita seperti Cut Nyak Dien, Dewi Sartika, ataupun Raden Ajeng Kartini. Meskipun begitu, perjuangannya dalam dunia pendidikan tidak dapat diragukan lagi. Sebuah 
nama besar seorang Rahmah El-Yunusiah yang lahir pada tanggal 1 Rajab 1318 Hijriyah atau 20 Desember 1900 di jalan Lubuk Mata Kucing, Kanagarian, Bukit Surungan, Padang Panjang, tanah Minangkabau. Dia anak bungsu dari lima bersaudara, yaitu Zainuddin Labay (1890-1924 M), Mariah (1893-1972 M), Muhammad Rasyad (1895-1956 M), dan Rihanah (1898-1968 M)³ dan Rahmah masih mempunyai saudara lain ibu, yaitu Abdus Samad, Hamidah, Pakih Bandaro, Liah, Aminuddin, Safiah, Samihah dan Kamsiah. ${ }^{4}$

Ayahnya bernama Syaikh Muhammad Yunus (1846-1906 M) yang terkenal sebagai ulama besar dan seorang qadhi/ hakim yang ahli ilmu falak dan hisab di Pandai Sikat. Riwayat pendidikan ayahnya, Syaikh Muhammad Yunus pernah belajar selama 4 tahun di tanah suci Mekkah. Sedangkan ibunya bernama Rafi'ah dari keturunan suku Sikumbang yang berasal dari negeri Langkat, Bukittinggi Kabupaten Agam. Ibunya Rafi'ah juga masih berdarah keturunan ulama, empat tingkat diatasnya masih ada hubungan dengan mamak Haji Miskin, sang pembaharu gerakan Paderi. Ibunya berhijrah ke bukit Surungan Padang Panjang pada abad XVIII M yang lalu. Dan menikah dalam usia yang masih belia, 16 tahun sedangkan Syaikh Muhammad Yunus sudah berusia 42 tahun.

Kakeknya bernama Syeikh Imaduddin yang juga terkenal sebagai ulama ahli ilmu falak dan tokoh tarekat Naqsyabandiyah Khalidiyah di Tanah Minang. Beliau merupakan ulama yang masih ada darah keturunan dengan pembaharu Islam yang juga seorang tokoh Paderi, Tuanku Nan Pulang di Rao. ${ }^{5}$ Dari sini, berarti Rahmah hidup dalam keluarga dari kalangan ulama sehingga mudah baginya memperoleh pendidikan.

Kemudian dari latar belakang keluarganya yang taat beragama, Rahmah telah menempuh pendidikan dari ayahnya, namun masa belajar itu hanya berlangsung singkat karena ayahnya meninggal pada saat ia masih kanak-kanak. Kemudian dibesarkan oleh ibunya dan peran sang ayah digantikan oleh kedua kakaknya yakni Zainuddin Labay El-Yunusiy dan M. Rasyad yang sudah berumah tangga.

Kakaknya Zainuddin adalah salah seorang tokoh pembaharu di Sumatra Barat. Zainuddin Labay sendiri adalah pendiri Diniyah School di Sumatra. Kakaknya itu menguasai beberapa bahasa asing seperti Inggris, Arab, dan Belanda sehingga banyak membantu Rahmah mengakses sejumlah literatur asing. Rahmah sangat menyegani dan mengagumi kakaknya ini. Baginya Zainudin adalah seorang pemberi inspirasi, pendukung cita-cita, dan seorang guru baginya.

3 Abuddin Nata, Tokoh-tokoh Pembaruan dan Pendidikan Islam di Indonesia (Jakarta: Raja Grafindo Persada, 2005), 29.

${ }^{4}$ Abuddin Nata, Tokoh-tokoh Pembaruan, 29.

${ }^{5}$ Abuddin Nata, Tokoh-tokoh Pembaruan, 29. 
Dari keluarga terpandang yang berpendidikan dan beragama yang kuat Rahmah tidak mengalami kesulitan untuk memperoleh pendidikan. Rahmah bisa dibilang perempuan beruntung dengan keadannya. Berbeda halnya dengan perempuan-perempuan lain yang ada di masyarakat sekitarnya, hanya dapat memperoleh pendidikan dasar yang cukup dibekali dengan ketrampilan untuk mempersiapkan diri menjadi istri dan ibu yang mengurusi rumah tangga. Perempuan masih dalam batasan-batasan budaya sempit yang menghambat mereka untuk beraktualisasi diri, membuka wawasan dan memperdalam ilmu pengetahuan serta tampil berprestasi dihadapan publik.

Dan tidak dapat dielakkan sebagai seorang perempuan Minang, hal itulah juga yang membuat Rahmah mengikuti jejak ibunya. Ia menikah pada usia belia 16 tahun dengan seorang mubalig dan ulama muda berpikiran maju bernama $\mathrm{H}$. Baharuddin Lathif dari Sumpur Padang Panjang. ${ }^{6}$ Namun perkawinannya hanya berlangsung selama enam tahun. Pada tahun 1922 atas kehendak kedua belah pihak bersepakat bercerai dan memutuskan untuk menganggap sebagai dua bersaudara. Dari pernikahan ini Rahmah tidak memperoleh keturunan. Dan sejak perceraian tersebut, Rahmah tidak bersuami lagi. Sehingga disepanjang hidupnya ia curahkan untuk mengabdikan diri pada madrasah yang dibangunnya.

Dan di akhir masa hidupnya, pada hari Rabu tanggal 9 Zulhijjah 1388 Hijriyah atau tanggal 26 Februari 1969 pada pukul 19.30 di rumahnya sendiri di Padang Panjang, Rahmah El-Yunusiyah wafat pada usia 68 tahun 2 bulan. Jenazahnya dikuburkan di perkuburan keluarga disamping rumahnya yang juga disamping perguruan yang ia dirikan dipinggir jalan Lubuk Mata Kucing. Meskipun jasadnya telah mati terkubur namun jasa peninggalan perjuangannya bagi perempuan masih bisa terus dikenang. Pengorbanan dalam hidupnya tidaklah sia-sia, perjuangan dan dedikasinya dalam bidang pendidikan banyak memberi manfaat besar bagi agama, kehidupan masyarakat dan negara khususnya perempuan. Inilah nama besar Rahmah El-Yunusiyah sebagai ulama perempuan yang memperjuangkan pendidikan perempuan Indonesia.

\section{Riwayat Pendidikan Rahmah El-Yunusiyah}

Dari keterangan diatas telah dijelaskan awal pendidikan Rahmah telah diperoleh dari sang ayah dan dilanjutkan oleh kedua kakaknya. Meskipun hanya sebentar, karena ayahnya meninggal pada saat ia masih kanak-kanak. Selanjutnya, selain itu Rahmah kecil juga telah mendapat pendidikan formal sekolah dasar selama tiga tahun di kota kelahirannya, Padang Panjang. Ketika ia berusia 15

\footnotetext{
${ }^{6}$ Hamruni, “Pendidikan Perempuan Dalam Pemikiran Rahmah el-Yunusiyyah," diakses pada 5 April 2011, http://uinsuka.info/ejurnal/index.php?option=com content\&task=view\&id=95\&Itemid=52.
} 
tahun, pendidikan bahasa Arab dan Latin ia dapatkan dari Diniyah School yang didirikan kakaknya (1915).

Jiwa yang selalu merasa tidak puas dari dalam diri Rahmah menjadikannya merasa tidak cukup jika hanya menjadi siswa di Diniyah School, meski ia dapat menuntut ilmu dengan baik dan termasuk dalam siswa yang cerdas. Selain itu, Rahmah juga sangat kritis dalam menanggapi berbagai permasalahan, dari rasa ketidaktidakpuasannya dengan sistem koedukasi pada Diniyah School yang kurang memberikan penjelasan terbuka kepada siswa puteri mengenai persoalan khusus perempuan. ${ }^{7}$ Maka ia bersama ketiga temannya sesama wanita, yaitu Rasuna Said dari Maninjau, yang kemudian hari namanya diabadikan sebagai Pahlawan Nasional, Nanisah dari Bulaan Gadang Banuhampu, dan Jawana Basyir (Upik Japang) dari Lubuk Agung membicarakan masalah tersebut." Mereka berempat bersepakat untuk membentuk kelompok belajar. Rahmah mengajak ketiga temannya ini untuk menambah ilmu agama secara mendalam di luar perguruan di antaranya di Surau Jembatan Besi.

Tidak hanya belajar dengan kakaknya, Rahmah juga berguru dengan para ulama di Minangkabau seperti Haji Karim Amrullah (ayah Buya Hamka), Tuanku Mudo Abdul Hamid Hakim (pemimpin sekolah Thawalib Padang-Panjang), Syaikh Muhammad Jamil Jambek, Syaikh Abdul Latif Rasyidi, dan Syaikh Daud Rasyidi.8 Bila diwaktu paginya belajar di madrasah maka pada setiap sorenya, Rahmah remaja rutin mengaji pada Haji Abdul Karim Amrullah yang merupakan ayah dari Haji Abdul Malik Karim Amrullah atau Hamka di surau Jembatan Besi, Padang Panjang. ${ }^{9}$ Di sini ia memperdalam pengajian mengenai masalah agama dan wanita, disamping itu juga ia mempelajari bahasa Arab, fiqih dan ushul fiqih. Selama proses belajar inilah telah banyak mempengaruhi pemikiran Rahmah untuk melakukan pembaharuan pendidikan.

Dalam proses belajarnya, Rahmah boleh dikatakan merupakan sosok yang mengalami dua model pendidikan sekaligus yaitu pendidikan surau yang bersifat tradisional dan melalui madrasah yang dianggap lebih modern. Berada pada dua model pendidikan itu sendiri membuat Rahmah bisa menyelami kelebihan dan kekurangan masing-masing entitas. Oleh karena itu meskipun pada akhirnya Rahmah El-Yunusiah mengambil sistem pendidikan Madrasah, ia tetap

7 Aminuddin Rasyad dkk., Hj. Rahmah El Yunusiyah dan H. Zainuddin Labay El Yunusy Dua Bersaudara Tokoh Pembaharu Pendidikan Islam, 38.

8 Nidiya Zuraya, "Rahmah El-Yunusiyyah; Perintis Sekolah Wanita Islam di Indonesia", Republika, diakses pada 20 Maret 2011.

${ }^{9}$ Hamruni, "Pendidikan Perempuan Dalam Pemikiran Rahmah el-Yunusiyyah," diakses pada 5 April 2011,

http://uinsuka.info/ejurnal/index.php?option=com content\&task=view\&id=95\&Itemid=52. 
mengembangkan gagasan-gagasan dan aktivitas-aktivitas posistif yang ia dapatkan dari sistem surau. Dengan demikian surau sebagai lingkungan pendidikan tidak ditinggalkan dalam gagasan pendidikan Rahmah.

Inilah sosok Rahmah yang dikenal sebagai pribadi yang giat mencari ilmu. Jadi, selain belajar agama kepada sejumlah ulama, ia juga mempelajari dan menekuni berbagai ketrampilan yang mestinya dimiliki oleh kaum perempuan seperti memasak, menenun, dan menjahit. Ia juga berupaya menularkan ketrampilan ini kepada kaum perempuan yang ada di sekitarnya. Sehingga Rahma menjadi tokoh panutan, meski ia giat dalam belajar agama tapi juga tetap menguasai ketrampilan sebagaimana idealnya seorang perempuan.

Dimulai pada saat berumur 23 tahun, Rahmah mempunyai semangat dan keinginan yang besar untuk memajukan keilmuan kaumnya dan mengeluarkan kaumnya dari kebodohan kehidupan, utamanya dalam rumah tangga. Karena rumah tangga adalah bagian dari tiang masyarakat dan masyarakat adalah tiang negara. Tentulah ia tidak mau, kaumnya yang mempunyai peran penting dalam tiang negara dan pendidikan anak-anaknya tidak memperoleh hak pendidikan.

Dan pada akhirnya pada tanggal 01 November 1923, Rahmah dengan dukungan dari kakaknya, Zaenuddin Labay dan teman-teman perempuannya di PMDS (Persatuan Murid-murid Diniyah School) memutuskan untuk mendirikan sekolah khusus Perempuan yang dinamai Diniyah School Putri atau Madrasah Diniyah li al-Banat yang bertempat di Masjid Pasar Usang. Langkah awal yang pasti dan mampu memberikan tempat bagi perempuan untuk dapat memperoleh hak pendidikan. Pendidikan yang diharapkan akan membawa dampak besar bagi kehidupan masyarakatnya dan negara.

Setelah tujuh tahun mendirikan Diniyah School Putri, sekitar tahun 19311935, ia berfikir perlu untuk kembali menuntut ilmu kesehatan dengan mengikuti kursus ilmu kebidanan di RSU Kayu Tanam dan mendapat izin praktek/ ijazah bidan dari dokter. Dalam bidang kebidanan ini ia juga mendapat bimbingan yang mula-mula diberikan dari kakak ibunya Kudi Urai, seorang bidan yang menolong kelahiran dirinya dan Sutan Syahrir (Mantan Perdana Menteri RI). ${ }^{10}$

Disamping itu, masih dalam bidang kesehatan ia belajar ilmu kesehatan dan pertolongan pertama pada kecelakaan (P3K) dari enam orang dokter yang juga gurunya dalam kebidanan, yaitu dokter Sofyan Rasyad dan dokter Tazar di rumah sakit umum Kayu Tanam (mendapat izin praktek dan ijazah dengan kedua dokter ini), dokter A. Saleh di RSU Bukittinggi, dokter Arifin dari Payakumbuh, dan dokter Rasjidin dan

\footnotetext{
${ }^{10}$ Hamruni, "Pendidikan Perempuan Dalam Pemikiran Rahmah el-Yunusiyyah," diakses pada 5 April 2011, http://uinsuka.info/ejurnal/index.php?option=com content\&task=view\&id=95\&Itemid=52.
} 
dokter A. Sani di Padang Panjang. Untuk mendalami praktek kebidanan dan ilmu kesehatan ini ia belajar sambil praktek di RSU Kayu Tanam. ${ }^{11}$

Tidak hanya itu, Rahmah juga mempelajari olahraga dan senam dari Mej Oliver seorang guru di Normal School di Guguk Malintang. Banyak ilmu yang dipelajari Rahmah. Begitu pula penguasannya dalam berbagai bidang keilmuan yang menjadi modal besar dalam mengembangkan madrasah yang didirikannya. Banyak hal inilah yang telah menjadi manifestasi berharga dan selanjutnya dapat mempengaruhi metode pendidikannya yang diterapkan dalam madrasahnya. Satu hal penting yang selalu ia pegang bahwa pentingnya peranan pendidikan bagi perempuan untuk dapat mengangkat derajatnya.

\section{Konsep Pemikiran Rahmah El-Yunusiyah tentang Pendidikan Perempuan}

Pada masa itu di awal abad XX, situasi sosial Sumatra Barat sedang berubah. Penduduk Minangkabau berkembang menjadi masyarakat yang secara intensif mengalami proses modernisasi. Dalam kerangka pembaharuan Islam masyarakat Minang tidak saja menyaksikan berdirinya lembaga-lembaga pendidikan modern menggantikan lembaga pendidikan tradisional sistem surau, namun juga tampilnya sejumlah ulama yang mengetengahkan pemikiran baru yang disemangati oleh perubahan dan modernisasi.

Keluarga yang memiliki latar belakang taat beragama dan aktif dalam gerakan pembaharuan menjadi ladang bagi bersemainya kesadaran pembaharuan dalam diri Rahmah. Ia menilai bahwa kaum perempuan sebagai tiang negara mestinya mendapatkan pendidikan yang baik sebagai halnya kaum lelaki. Keterbelakangan pendidikan kaum perempuan ini menurutnya berakar dari persoalan pendidikan dan melalui bidang ini dapat terselesaikan.

Semangat untuk mengangkat harkat kaum muslimah ini rupanya telah terpatri dengan mendapat landasan yang kokoh dalam ajaran Islam yang secara tegas menyebutkan: "Menuntut ilmu itu wajib bagi tiap-tiap orang Islam laki-laki dan perempuan". Jika kaum perempuan tidak mendapatkan ilmu yang memadai, maka bahaya akan datang dalam lingkungan masyarakat. Namun jika pendidikan yang diberikan kepada mereka itu keliru, maka tidak sedikit pula malapetaka yang akan menimpa bagi segenap masyarakat manusia. Berhubung dengan itu maka pendidikan terhadap kaum wanita hendaknya disertai dengan berbagai macam kebijaksanaan, tidak boleh dilakukan secara serampangan. ${ }^{12}$

11 Abuddin Nata, Tokoh-tokoh Pembaruan, 110.

12 Moenawar Kholil, Nilai Wanita (Surakarta: CV. Ramadhani, 1989), 115. 
Sistem pendidikan yang sebelumnya bercorak tradisional kurang memberikan akses bagi perempuan. Selain itu kurang penekanannya terhadap akses untuk masuk dunia kerja dan kesempatan lain. Dalam situasi masyarakat yang sedang bertumbuh inilah Rahmah El-Yunusiah tergugah untuk berkiprah. Ia menaruh perhatian khusus terhadap pendidikan kaum perempuan. Ia menyadari bahwa pendidikan menjadi sarana utama bagi peningkatan posisi kaumnya.

Penduduk Minang, dimana Rahmah El-Yunusiah tumbuh juga dikenal sebagai masyarakat yang agamis. Masyarakat ini memang pernah terbelah dalam era Perang Padri (1821-1837), dimana terjadi konflik antara kelompok pemangku adat yang ingin melestarikan tradisi lama berlawanan dengan kaum padri yang ingin mengembangkan kehidupan keagamaan secara totalitas. Rekonsiliasi terjadi pada tahun 1840 setelah kedua belah pihak menyadari kekeliruannya. Kesepakatan kedua belah pihak dikukuhkan dalam bai'at yang dikenal dengan nama Piagam Bukit Marapalam yang isinya mengaskan bahwa adeik basandi syara'- syara' basandi kitabullah (Adat bersendi syara'- syara' bersendi kitabullah). Syara' yang dimaksud adalah ajaran Islam dan kitabullah menunjuk pada $\mathrm{Al}$ Qur'an. Ungkapan yang dihasilkan dalam kesepakatan ini, lagi-lagi menunjukkan bahwa pada dasarnya masyarakat Minang adalah religius. ${ }^{13}$

Meskipun Rahmah El-Yunusiah sempat mengenyam pendidikan agama dari model Surau, namun tetap saja perempuan memiliki keterbatasan dalam lingkungan pendidikan ini. Perempuan tidak bisa sebebas kaum laki-laki dalam menuntut ilmu di Surau. Kaum lelaki Minang memang dikenal sangat santun terhadap kaum wanita. Bahkan menjadi aib apabila ada seorang pria tidur di rumah, sementara di rumah yang sama saudara wanitanya juga tidur. Wanita juga mendapat kekhususan yang lebih utama dari laki-laki dalam hal harta pusaka (warisan). Alam Minang sendiri mengenal tradisi matrilineal, dimana kaum perempuan dianggap memiliki keutamaan dalam hal tertentu. ${ }^{14}$ Meskipun demikian akses perempuan untuk mendapat ilmu agama tetap terbatas.

Keterbatasan dalam hal akses keilmuan inilah yang nampaknya mendorong Rahmah ikut terlibat dalam arus "pembaharuan" bagi kaum perempuan. Meskipun demikian Rahmah nampaknya tidak memiliki gagasan bahwa kondisi keterbelakangan kaumnya ini terjadi sebagai akibat kondisi sosial yang cenderung patriarkhis atau bahkan buah penindasan yang terjadi karena kaum lelaki. Pijakan awal pembaharuan yang dibawa oleh Rahmah dalam konsepnya tentang pendidikan kaum perempuan jelas berbeda dengan asumsi

\footnotetext{
${ }^{13}$ Febri Yulika, Epistemologi Minangkabau: Makna Pengetahuan dalam Filsafat Adat Minangkabau (Yogyakarta: Gre Publishing, 2012), 3.

${ }^{14}$ Tuanku Kayo Khadimullah, Menuju Tegaknya Syariat Islam di Minangkabau: Peranan Ulama Sufi dalam Pembaruan Adat (Bandung: Marja, 2007), 171-172.
} 
dasar kaum feminis yang menganggap bahwa kaum perempuan mengalami diskriminasi. ${ }^{15}$

Apalagi dengan melihat kembali budaya alam Minangkabau yang dari beberapa sisi cenderung memuliakan kaum perempuan, maka perbedaan antara kesadaran awal Rahmah El-Yunusiah dengan asumsi feminisme semakin kentara. Wacana yang diusung Rahmah El-Yunusiah bukanlah upaya "membebaskan" atau bahkan "memerdekakan" sebagaimana yang ada dalam konsep emansipasi Barat, sebab hakikatnya wanita di ranah Minang memang tidak dalam kondisi diperbudak atau terjajah oleh pria. Ia hanya menginginkan agar wanita mendapatkan posisinya sebagaimana ajaran Islam menempatkan kaum perempuan.

Pandangan Rahmah El-Yunusiah terhadap perempuan terlihat jelas berpangkal dari ajaran Islam. Fakta sosial tentang adanya ketimpangan atau penindasan yang kadang terjadi di kalangan masyarakat Islam lebih banyak terjadi disebabkan oleh praktik dan tradisi masyarakat yang bersangkutan, ketimbang oleh ajaran Islam. Pandangan demikian tentu berbeda dengan konsep kesetaraan gender yang dipahami oleh kalangan feminis radikal yang menganggap bahwa ajaran Islam adalah sumber budaya patriarkhis, oleh karena itu ajaran Islam itu sendiri adalah salah karena menampakkan misogyny (bias gender) dan harus dikoreksi. ${ }^{16}$

Rahmah menilai bahwa posisi kaum perempuan dalam Islam cukup sentral, dalam hal ini tidak ada perbedaan dengan kaum laki-laki. Perbedaan peran memang ada, namun hal ini bukan merupakan wilayah yang kemudian dijadikan pembenaran sebagai bukti adanya suatu diskriminasi. Ia hanya berupaya memperbaiki kondisi kaumnya melalui bidang pendidikan, sebab menurutnya wanita pada akhirnya akan berperan sebagai seorang ibu. Ibu merupakan madrasah awal bagi anak-anaknya sebelum terhubung dengan alam pandang (worldview) yang lebih luas di lingkungan sekitarnya. Melalui ibu inilah corak pandang dan kepribadian awal seorang anak akan terbentuk. Oleh karena itu menjadi penting bagi Rahmah untuk memberikan bekal bagi kaum perempuan ilmu-ilmu agama dan ilmu terkait lainnya sehingga bisa memiliki pengetahuan yang sama dengan mitra sejajarnya, kaum lelaki. Di sini pula akan terbentuk

15 Gillian Howie, Between Feminism and Materialism: A Question of Method (New York: Palgrave Macmillan, 2010), 27-28; Mansour Fakih, et.al., Membincang Feminisme: Diskursus Gender Perspektif Islam (Surabaya: Risalah Gusti, 2000), 38; A. Nunuk P. Murniati, Getar Gender: Perempuan Indonesia dalam Perspektif Sosial, Politik, Ekonomi, Hukum, dan HAM (Magelang: Indonesia Tera, 2004), xxviii.

Lihat juga Syamsuddin Arif, Orientalis dan Diabolisme Pemikiran (Jakarta: Gema Insani, 2008), 103-107.

${ }^{16}$ Syamsuddin Arif, Orientalis dan Diabolisme, 113. 
pandangan bahwa wanita merupakan tiang negara dan penentu masa depan bangsa.

Kajian ilmiah modern dan data-data akurat telah mengungkapkan bahwa ibu memegang peranan sangat penting dalam perkembangan anak-anak. Perkembangan ini mencakup badan, kesehatan, kemampuan intelektualitas, serta perkembangan kejiwaan dan perilakunya, hingga hal-hal yang lainnya. ${ }^{17}$ Intinya ibu memiliki peran tertentu dalam mendidik anak-anak, termasuk dalam pemahaman keagamaan. Pada wilayah inilah nampaknya Rahmah El-Yunusiah bergerak, tentu saja terlepas dari fakta hasil kajian ilmiah modern dan data-data terkait yang baru ada setelah masa sesudahnya.

Inilah jalan pendidikan yang menjadi pemikiran Rahmah, tidak hanya terpaku dalam kebudayaan dan tradisi masyarakatnya yang tertutup bagi perempuan tapi bagaimana konsep pendidikan yang berdasarkan Islam dapat menyesuaikan dan menjadi solusi untuk perkembangan pendidikan perempuan. Dipadukan lagi dengan sistem pendidikan tradisional surau yang mulai tergantikan dengan sistem pendidikan madrasah yang selangkah lebih modern. Dan terus ada upaya dari Rahmah untuk melakukan pembaharuan di bidang pendidikan khususnya pendidikan bagi perempuan.

Dilihat dari aktivitas yang dilakukannya, nampaknya Rahmah El-Yunusiah ingin menerapkan "pembelajaran sepanjang hayat" dalam konsep pendidikan yang digagasnya. Hal ini tercermin dalam model pendidikan yang dimulai dari masa anak-anak sampai perguruan tinggi. Dan dari madrasah-madrasah yang dibangun dan dikembangkannya yang dimulai dari jenjang taman kanak-kanak hingga perguruan tinggi. Pendidikan yang tidak mengenal usia baik yang masih anak-anak maupun yang sudah renta. Hal ini berlaku selama manusia masih bernafas maka masih dianjurkan menuntut ilmu.

\section{E. Diniyah School Putri atau Madrasah Diniyah li al-Banat}

Berbekal dari perjalanan hidupnya dalam mencari ilmu dan berguru kepada tokoh-tokoh ulama besar, maka timbullah keinginan kuat dari Rahmah untuk mencerdaskan kaum perempuan. Rahmah merasa kaum muslimah harus mendapatkan hak pendidikan. Namun sudah menjadi kenyataan umum pada waktu itu bahwa yang mendirikan dan menyelenggarakan dunia pendidikan adalah kaum pria. Di Pulau Jawa misalnya semua pesantren didirikan oleh kaum pria. Apalagi pada masa itu adat sangat kuat di Minangkabau. Tapi Rahmah ElYunusiyah dapat menunjukkan kepada masyarakat dan kepada dunia, bahwa wanita dapat berbuat sebagaimana halnya kaum pria.

\footnotetext{
${ }^{17}$ Nuruddin 'Itr, Hak dan Kewajiban Perempuan: Mempertanyakan Ada Apa Dengan Wanita? (Yogyakarta: Bina Media, 2005), 156-157.
} 
Visi Rahmah tentang peran perempuan adalah peran dengan beberapa segi: sebagai pendidik, pekerja sosial demi kesejahteraan masyarakat, teladan moral, muslim yang baik dan juru bicara untuk mendakwahkan pesan-pesan Islam. Sebelum Rahmah mempeloporinya dengan bepergian dan berpidato dalam rangka mengumpulkan dana, kaum perempuan tidak pernah berpidato dalam acara-acara keagamaan atau adat dihadapan para pendengar yang bercampur antara laki -laki dan perempuan. Pandangan yang berkembang di Minangkabau pada masa itu adalah bahwa secara moral tidak pantas, bahkan haram, bagi seorang perempuan berpidato di depan hadirin di mana terdapat kaum laki-laki. Pada tahun 1930 Muhammadiyah, sebuah organisasi modernis, mampu menegosiasikan dikeluarkannya fatwa yang menyatakan bahwa perempuan tidak secara eksplisit dilarang berpidato di depan hadirin yang mencakup kaum lakilaki.

Dari perkembangan masayarakat tersebut, maka cita-cita besar Rahmah ini dalam tujuh tahun sebelumnya sudah dimanifestasikan dengan mendirikan lembaga pendidikan khusus perempuan yang dinamai dengan Diniyah School Putri pada tanggal 1 November 1923. Inspirasi yang juga timbul dari Diniyah School milik sang kakak, dengan memisahkan proses pendidikan antara laki-laki dan perempuan.

Pada awalnya, muridnya berjumlah 71 orang dan terdiri dari ibu-ibu muda, termasuk putri dari Teungku Panglima Polim dan Hajjah Rangkayo Rasuna Said. Pelajaran yang ajarkan yaitu ilmu agama dan tata bahasa Arab, namun dalam perkembangannya sekolah ini menerapkan pendidikan modern dengan menggabungkan pendidikan agama, pendidikan sekuler dan pendidikan keterampilan.

Diniyah School Puteri ini selalu akan mengikhtiarkan penerangan agama dan meluaskan kemajuannya kepada perempuan-perempuan yang selama ini susah mendapatkan penerangan agama Islam dengan secukupnya daripada kaum Lelaki. Inilah yang menyebabkan terjauhnya penerangan perempuan Islam daripada penerangan agamanya sehingga menjadikan kaum perempuan itu rendam karam ke dalam kejahilan, kata Rahmah. ${ }^{18}$

Di samping mendirikan Diniyah School Putri, ia pun mendirikan Menyesal School, yaitu sekolah pemberantasan buta huruf di kalangan ibu-ibu rumah tangga. Sekolah ini didirikan pada tahun 1925 dan berlangsung selama tujuh tahun yaitu sampai tahun 1932. Kemudian sekolah ini tidak dilanjutkan. Untuk

18 Junaidatul Munawaroh, Rahmah El - Yunusiyah: Pelopor Pendidikan Perempuan, ed. Jajat Burhanudin (Jakarta: Gramedia Pustaka, 2000), 1. dan Jajat Burhanudin, Tentang Perempuan Islam: Wacana dan Gerakan, ed. Oman Fathurrahman (Jakarta: Gramedia Pustaka Utama, 2004), 19. 
menyebarluaskan cita-cita pendidikannya, ia mengadakan perjalanan berkeliling ke daerah Sumatera Utara, Sumatera Selatan, Jambi dan Semenanjung Malaya (tahun 1928 dan tahun 1934).

Landasan ideal dari pelaksanaan cita-citanya yaitu berpegang kepada AlQur`an dan As-sunnah. Sedangkan tujuan pendidikan Diniyah Puteri yang ia kembangkan adalah: "Membentuk puteri yang berjiwa Islam dan ibu pendidik yang cakap dan aktif serta betanggung jawab tentang kesejahteraan masyarakat dan tanah air atas dasar pengabdian Allah subhanahu wata'ala".

Adapun perkembangan Diniyah School Putri menerapkan cara belajar di yang sangat sederhana. Lokasi belajarnya mengambil tempat disalah satu ruangan Masjid Pasar Usang, murid-murid duduk dilantai sambil mengelilingi guru menghadap sebuah meja kecil. Guru-gurunya ada empat, yaitu Rahmah merangkap sebagai pemimpin, Darwisah, Nasisah, dan Djawena Basyir. Pada tahun 1924 perguruan ini dipindahkan ketempat yang baru, dengan menyewa rumah bertingkat dua yang berlokasi di Pasar Usang Padang Panjang. Sejak itu perguruan ini dilengkapi dengan bangku, meja, dan papan tulis. Anak-anak yang belum berumah tangga diharuskan tinggal di asrama yang disediakan pada tingkat dua.

Karena perhatian masyarakat bertambah besar terhadap perguruan ini dengan banyaknya murid-murid yang datang dari luar Kota Padang Panjang, pada awal tahun 1926 dibangun sebuah gedung yang lengkap dengan asramanya. Namun tiga tahun kemudian, gempa hebat mengguncang Sumatera Barat, bangunan sekolah dan asrama yang baru ia rintis luluh lantak, meski begitu Rahmah tidak menyerah, Rahmah langsung bangkit kembali. Dengan susah payah, ia membangun kembali sekolahnya dengan batangan bambu dua lantai dan menghimpun kembali para muridnya.

Banyak pihak yang menawarkan bantuan secara finansial, salah satunya adalah pemerintah Belanda. Pemerintah Belanda menawarkan bantuan untuk membantu sekolahnya dengan subsidi penuh dengan syarat Diniyyah Puteri menjadi lembaga yang berada dibawah pengawasan Belanda. Rahmah pun menolak dengan tegas, ia tidak mau sistem pendidikan yang sudah terbangun dengan baik dibelokkan oleh Belanda. ${ }^{19}$ Lalu ia memutuskan untuk bersama-sama dengan majelis guru dan dibantu oleh murid-murid Thawalib School Padang Panjang, kembali secara gotong royong mendirikan beberapa rumah bambu diatas sebidang tanah wakaf dari ibunya, Ummi Rafi'ah, dengan atap daun rumbia berlantaikan tanah.

${ }^{19}$ Azyumardi Azra, Ensiklopedi Islam "Rahmah el-Yunusiyyah" Jilid 4 NAH-SYA (Jakarta: Ichtiar Baru Van Hoeve, 1997), 152.

Jurnal Pendidikan Agama Islam

Volume 4 Nomor 1 Mei 2016

ISSN(p) 2089-1946 \& ISSN(e) 2527-4511

Hal. 14 - 19 
Pada tahun 1927 Rahmah pergi ke Sumatera untuk mengumpulkan dana guna membangun sebuah gedung permanen yang baru. Gedung ini selesai pada tahun berikutnya. Sesuai dengan tingkat kebutuhan, perguruan ini terus-menerus mengalami penyempurnaan, baik fisik, jenis lembaga pendidikan, maupun kurikulum. Perjalanan yang tidak singkat dan penuh rintangan. Namun karena kegigihannya, dana yang diperoleh dapat memenuhi keperluan yang sudah menjadi tujuan sejak awal.

Dalam kurikulum dan Sistem Pendidikan Diniyyah Putri sejak berdirinya, selalu mempertahankan sistem pendidikan tritunggal, yaitu kerja sama yang erat antara lingkungan sekolah, asrama, dan rumah tangga atau masyarakat. Dengan sistem pendidikan yang dianut oleh perguruan ini terjalinlah kerja sama yang erat antara ketiga macam sistem lingkungan untuk mencapai tujuan sesuai dengan yang telah digariskan. Ini berarti bahwa pendidikan yang diberikan secara formal di pagi hari di praktikkan di asrama secara informal dibawah asuhan dan bimbingan ibu asrama dan guru-guru pengasuh yang seluruhnya adalah guruguru wanita. Kemudian, semua materi pendidikan yang pernah diterima oleh pelajar selama mereka berada di perguruan ini di praktikkan di lingkungan keluarga dan masyarakat sekitarnya dibawah pengasuhan orang tuanya. Lebih dari itu, untuk mengembangkan pengetahuannya tentang kurikulum sekolah, Rahmah juga melakukan studi banding melalui kunjungan-kunjungan sekolah ke Sumatera dan Jawa (1931).

Perpaduan sistem kurikulum yang dicanangkan dalam diniyah school menggambarkan tentang sistem pendidikan yang melibatkan berbagai pihak. Tujuan pendidikan dapat diwujudkan melalui kerja sama yang erat antara sekolah, keluarga dan masyarakat. Pendidikan tidak serta merta diserahkan sepenuhnya kepada madrasah tapi juga harus mendapat dukungan dari keluarga dan masyarakatnya untuk dapat langsung mengaplikasikan ilmu yang didapatkan siswa dari madrasah. Maka terdapat sinergisitas dalam memajukan pendidikan dan peningkatan kualitasnya dari pihak-pihak tersebut.

Usaha keras panjang yang terus dilakukan Rahmah dapat membuahkan hasil hingga pada lembaga pendidikan di lingkungan Perguruan Diniyyah Putri terdiri dari empat jenjang. ${ }^{20}$ Pertama, perguruan Diniyyah Putri Menengah Pertama (DMP) bagian B. Lama pendidikan 4 tahun. Perguruan ini menampung murid-murid tamatan Sekolah Dasar (SD) atau sederajat. Kedua, Perguruan Diniyyah Putri Menengah Pertama (DMP) bagian C. Lama pendidikan 2 tahun. Dan menerima murid-murid tamatan SLTP (Sekolah Lanjutan Tingkat Pertama) atau sederajat. Ketiga, kulliyah Al-Muallimat al-Islamiyah (KMI). Lama pendidikan 3 
tahun dan menampung murid murid-murid tamatan DMP. Bagian B dan C atau dari Perguruan Agama Tinggi Menengah atau Tsanawiyah. Keempat, Fakultas Dirosah Islamiyah Perguruan Tinggi Diniyah Putri. Lama pendidikannya 3 tahun untuk mendapatkan ijazah tingkat Sarjana Muda setingkat dengan Fakultas Ushuluddin IAIN. Status fakultas diakui dengan SK. Menteri Agama No.117 tahun 1969.

Lembaga pendidikan ini telah menjadi bukti dari perjuangan pembaharuan pendidikan yang dilakukan Rahmah. Yang pada awalnya perempuan hanya memperoleh pendidikan dasar namun karena perjuangannya dalam mendirikan lembaga pendidikan diniyah putri, perempuan dapat mengenyam pendidikan hingga perguruan tinggi. Dan dapat dilihat dampaknya, posisi perempuan telah meningkat derajatnya. Perempuan dapat mengakses pendidikan dengan mudah dan menjadi tokoh publik yang ikut berpartisipasi dalam kegiatan sosial masyarakat.

Seiring berjalannya waktu, perkembangan Diniyah Putri ternyata tidak hanya didengar dalam lingkup nasional saja, tapi sudah tersiar sampai luar negeri. Perhatian luar negeri terhadap pola pendidikan Diniyyah Putri diperoleh dari Malaysia, Singapura dan bahkan juga Negara-negara Timur Tengah. Pada tahun 1955, Rektor Al-Azhar University, Syekh Abdur Rahman Taj datang mengunjungi Diniyyah Putri dan menyatakan kekagumannya dan tertarik dengan sistem pembelajaran khusus yang ada di sekolah tersebut. Tidak lama setelah kunjungan tersebut, kampus Islam tertua di dunia itu membuka pendidikan khusus Perempuan yang bernama kulliyyât al-banât. Waktu itu memang, Al Azhar belum memiliki sekolah pendidikan khusus perempuan.

Begitu berkesan dunia internasional terhadap Rahmah El-Yunusiyah yang telah memperjuangkan kaum perempuan dalam memperoleh hak pendidikan. Langkah konkret yang dilakukannya dengan membangun lembaga pendidikan khusus perempuan yang ternyata dapat menjadi acuan bagi universitas terkemuka dunia internasional sekelas Al-Azhar Mesir untuk mendirikan pendidikan khusus pula bagi perempuan. Maka tidak berlebihan bila sosok Rahmah disematkan sebagai tokoh pembaharu pendidikan bagi perempuan yang telah mendedikasikan sepanjang usianya dalam dunia pendidikan. Sebagai penghargaan terhadap prestasinya, kemudian Al-Azhar mengundang Rahmah ElYunusiah untuk berkunjung ke perguruan tinggi tersebut pada tahun 1956.

Dalam kunjungan itu, Rahmah mendapat gelar kehormatan agama yang tertinggi yang diberikan dalam rapat senat guru besar Al-Azhar, dengan nama "Syaikhah"21. Gelar istimewa yang diberikan hanya untuk orang-orang yang ahli

${ }^{21}$ Nidia Zuraya, "Membangun Kemandirian Perempuan", Republika, diakses pada 20 Maret 2011. 
dalam bidang tertentu dan menguasai khazanah ilmu-ilmu keislaman. Gelar tersebut setara dengan gelar Syaikh Mahmoud Shaltout, yang merupakan mantan Rektor Al Azhar. Semenjak itulah, hubungan Diniyyah Putri semakin bertambah kokoh dengan berbagai perguruan tinggi yang ada di Timur Tengah. Hal ini juga telah memperkuat ukhuwah islamiyah antara negara-negara Islam.

Sungguh tidak mudah mendapatkan pengakuan dari dunia internasional. Maka dari sinilah telah terpampang jelas perjuangan panjang Rahmah yang penuh rintangan. Untuk mewujudkan cita-citanya dalam bidang pendidikan banyak sekali tantangan yang dihadapi Rahmah pada waktu sekolah itu didirikan. Masyarakat yang masih berpegang teguh dengan tradisi lama selalu melancarkan kritik dan cemoohan terhadapnya. Kata-kata seperti "mana pula orang perempuan akan mengajar, akan jadi guru, mengepit-ngepit buku, membuang-buang waktu²2. Akhirnya akan ke dapur juga, lebih baik dari kini ke dapur, sering dilontarkan kepadanya, tetapi berkat keyakinan yang mantap dan berpegang teguh kepada janji Allah dalam Al-Quran surat Muhammad ayat 7 yang menjelaskan jika kamu menolong (agama) Allah, niscaya Dia akan menolongmu dan meneguhkan kedudukanmu. Ia melangkah maju, menghadapi segala tantangan dan rintangan. Ayat diatas selalu ia jadikan pegangan, baik pada masa penjajahan Belanda, Jepang, maupun masa kemerdekaan dan hingga akhir perjuangannya pada saat menutup mata.

\section{F. Penutup}

Dari pemaparan diatas, dapat disimpulkan bahwa tokoh Rahmah ElYunusiyah adalah tokoh ulama perempuan nusantara yang telah jelas melakukan perjuangan dalam pendidikan perempuan. Dengan menelaah pemikiran pembaharuannya dapat memberi gambaran bahwa perempuan juga dapat berkiprah dalam ranah publik dan lingkungan sosialnya tanpa meninggalkan tugas pokoknya sebagai istri maupun ibu. Kiprahnya ini juga dapat dijadikan landasan bahwa perempuan juga dapat memiliki kesempatan yang sama dengan laki-laki dan bahkan menjadi pemimpin. Sosoknya yang gigih dan kuat menggambarkan representasi seorang ulama dan sebagai pemimpin umat dengan kapasitas keilmuan yang memadai dan mumpuni serta mempunyai jiwa sosial kemasyarakatan yang tinggi dan kepedulian pada kaumnya.

Cita-citanya yang besar bukan hanya sekedar berupa wacana ataupun angan-angan, namun telah diwujudkan dengan mendirikan sekolah-sekolah pada Perguruan Diniyyah Putri yang terdiri dari empat jenjang. Mulai dari jenjang

22 Aminuddin Rasyad, Rahmah el Yunusiyah: Kartini dari Perguruan Islam dalam Manusia dalam Kemelut Sejarah (Jakarta: Lembaga Penelitian Pendidikan dan Penerangan, 1978), 226. 
Sekolah Dasar (SD) atau Menengah Pertama (DMP) bagian B, Menengah Pertama (DMP) bagian C, Kulliyah Al-Muallimat al-Islamiyah (KMI), dan Fakultas Dirosah Islamiyah Perguruan Tinggi Diniyah Putri. Dengan prestasi yang gemilang ini, Rahmah telah mendapat gelar kehormatan agama yang tertinggi yang diberikan dalam rapat senat guru besar Al-Azhar, dengan nama "Syaikhah". Gelar istimewa yang diberikan hanya untuk orang-orang yang ahli dalam bidang tertentu dan menguasai khazanah ilmu-ilmu keislaman. Hal ini, sekaligus menjadi bukti pengakuan dunia internasional terhadap sosok ulama perempuan nusantara ini, Rahmah El-Yunusiyah.

\section{G. Referensi}

'Itr, Nuruddin. Hak dan Kewajiban Perempuan: Mempertanyakan Ada Apa Dengan Wanita? Yogyakarta: Bina Media, 2005.

Arif, Syamsuddin. Orientalis dan Diabolisme Pemikiran. Jakarta: Gema Insani, 2008. Azra, Azyumardi. Ensiklopedi Islam. Jakarta: Ichtiar Baru Van Hoeve, 1997.

Burhanudin, Jajat. Tentang Perempuan Islam: Wacana dan Gerakan. Disunting oleh Oman Fathurrahman. Jakarta: Gramedia Pustaka Utama, 2004.

Dhaif, Syauqi. Almu’jam Alwasịt I. Kairo: Maktabah Shurouq ad-Dauliyyah, 2011.

Hamruni. "Pendidikan Perempuan Dalam Pemikiran Rahmah el-Yunusiyyah." http://uinsuka.info/ejurnal/index.php?option=com_content\&task=view\&id =95\&Itemid=52, 2011 .

Howie, Gillian. Between Feminisme and Materialism: A Question of Method. New York: Palgrave Macmillan, 2010.

Jawad, Haiffa A. The Rights of Women in Islam: an Authentic Approach. New York: St. Martin's Press, Inc., 1998.

Khadimullah, Tuanku Kayo. Menuju Tegaknya Syariat Islam di Minangkabau: Peranan Ulama Sufi dalam Pembaruan Adat. Bandung: Marja, 2007.

Kholil, Moenawar. Nilai Wanita. Surakarta: CV. Ramadhani, 1989.

Mansour Fakih, et.al. Membincang Feminisme: Diskursus Gender Perspektif Islam. Surabaya: Risalah Gusti, 2000.

Manzur, Ibn. Lisān al-``Arab II. 1290.

Munawaroh, Junaidatul. Rahmah El - Yunusiyah: Pelopor Pendidikan Perempuan. Disunting oleh Jajat Burhanudin. Jakarta: Gramedia Pustaka, 2000.

Murniati, A. Nunuk P. Getar Gender: Perempuan Indonesia dalam Perspektif Sosial, Politik, Ekonomi, Hukum, dan HAM. Magelang: Indonesia Tera, 2004. 
Perempuan and Dedikasi dalam Pendidikan Islam

Nata, Abuddin. Tokoh-tokoh Pembaruan dan Pendidikan Islam di Indonesia. Jakarta: Raja Grafindo Persada, 2005.

Rasyad, Aminuddin. Rahmah el Yunusiyah: Kartini dari Perguruan Islam dalam Manusia dalam Kemelut Sejarah. Jakarta: Lembaga Penelitian Pendidikan dan Penerangan, 1978.

Yulika, Febri. Epistemologi Minangkabau: Makna Pengetahuan dalam Filsafat Adat Minangkabau. Yogyakarta: Gre Publishing, 2012.

Zuraya, Nidia. “Membangun Kemandirian Perempuan.” (Republika) Maret 2011.

Zuraya, Nidiya. "Rahmah El-Yunusiyyah; Perintis Sekolah Wanita Islam di Indonesia." Republika, 2011. 